\title{
Follow up study of children born elsewhere but attending schools in Seascale, West Cumbria (schools cohort)
}

\author{
M J GARDNER, A J HALL, S DOWNES, J D TERRELL
}

\begin{abstract}
Records on 1546 children who were identified as-having attended schools in Seascale up to November 1984 and were born since. 1950 but not in the civil parish were studied. These children lived in or near Seascale for a period of time while they were attending one or more of three local schools and are an additional group to the 1068 children who were identified as born to mothers resident in Seascale in an accompanying study. Even though some of the schoolchildren apparently remained in the village for a short period only all but $7 \%$ were followed up through the National Health Service Central Register. Mortality among these children to 30 June 1986 is comparable to that expected at national rates. From all causes there were 10 observed deaths compared with 12.69 expected-a ratio of 0.79 (95\% confidence interval 0.38 to 1.45)_and from cancer one observed death compared with 2.04 expected-a ratio of $0.49(95 \% \mathrm{CI} 0.01$ to 2.73$)$. No deaths from leukaemia or lymphoma were reported, but only 0.83 was expected. Since 1971 (the year when cases of cancer were first notified to the NHS Central Register) three non-fatal cases of cancer were reported, including two lymphomas, compared with 2.04 expected and two cases of carcinoma in situ of the cervix compared with 1.79 expected. In addition, there was a case of
\end{abstract}

MRC Environmental Epidemiology Unit (University of Southampton), Southampton General Hospital, Southampton SO9 4XY

M J GARDNER, PHD, professor of medical statistics

A J HALL, MRCP, epidemiologist

S DOWNES, BSC, research assistant

West Cumbria Health Authority, West Cumberland Hospital, Hensingham, Whitehaven, Cumbria CA28 8jG

J D TERRELL, FFCM, district medical officer

Correspondence to: Professor Gardner. leukaemia among the schoolchildren which was known previously and had been diagnosed in 1968 .

There is an interesting difference between the results of this study and the results of the study of children born to mothers who were resident in Seascale. In the latter study there was an excess of leukaemia and of other cancers, but a similar finding is not apparent among children who spent some time at schools in Seascale but were born elsewhere. This raises the question of whether one or more aetiological factors in childhood cancer were acting on a locality specific basis before birth or early in life. This cannot be answered from these cohort studies, but it is hoped that the case-control study that is under way in West Cumbria will provide relevant information.

\section{Introduction}

The Black report made recommendations for four epidemiological studies related to childhood cancer in West Cumbria and the village of Seascale, which is close to the Sellafield nuclear fuel reprocessing site. ${ }^{1}$ Some of the rationale for these is given in the accompanying paper ( $p$ 822), which reports the results of one of the investigationsnamely, the follow up of children born since 1950 to mothers resident in Seascale at the time of birth (recommendation 2).

The third recommendation was that "a study should be considered of the records of schoolchildren who have attended schools in the area." After due consideration the records were found to be suitable to proceed, and this paper reports the methodology and the findings on mortality and cancer registration of this second follow up study.

\section{Methods}

We were made aware of four schools in Seascale which had taken pupils for all or some of the period from 1950. With the cooperation of the local 
education department, headmasters, and headmistresses we examined the school registers to find out whether the information in them was sufficiently detailed to identify uniquely the children who had attended. For three of the schools the recorded details were of suitable quality for follow up. The fourth school was a preparatory boarding school for boys which closed during 1972 but had taken some 150 pupils since 1950, of whom about half came from outside Cumbria. Although for each boy the year of birth was recorded, the full date of birth was not and hence follow up through the National Health Service Central Register was not feasible. This school had, therefore, to be omitted.

Children who had attended the other three schools, and who were born since 1 January 1950 as in the Seascale birth cohort, were included in the study. But any schoolchildren who were also born to mothers resident in Seascale Civil Parish at the time of birth, and so were already members of the birth cohort, were left out of this study.

Singing Surf School-This was a small coeducational school in Seascale that was open from 1949 to 1968 and mainly took children at preschool ages. Only 168 children born since 1950 were recorded as having attended. Among these were 44 who were already included in the Seascale birth cohort, and thus 124 children were identified for follow up.

Seascale local authority school-This is the main local village school. A total of 1930 pupils who were born since 1 January 1950 and entered the school up to November 1984 were recorded in the school register. Of these children, $565(29 \%)$ had already been identified in the Seascale birth cohort, and a further 54 (3\%) had previously attended Singing Surf School. The remaining $1311(68 \%)$ children, who must have moved into Seascale since birth or lived nearby, were included in the follow up.

Calder Girls School-This was a boarding school for girls that was open from 1950 to 1967. Altogether 114 girls born from 1950 onwards were recorded in the school register as having attended, many of whom came from far away, some from abroad. Only one of the 114 girls was in the Seascale birth cohort, one other had earlier attended Singing Surf School, and a further one the local authority school. The remaining 111 girls were thus included in the follow up.

The allocation of children to birth and schools cohorts in the way described was carried out to avoid duplication in counting children and events such as cancer registration and death. Table I gives the numbers of children in the various cohorts and their interrelationships. A total of 2614 children were followed up (given by summing the figures in the first column of the table), of which $1068(41 \%)$ are in the birth cohort and the remaining $1546(59 \%)$ in the schools cohort.

TABLE I-Numbers of children in Seascale birth cohort and schools cohort by register of first identification

\begin{tabular}{|c|c|c|c|c|}
\hline \multirow[b]{2}{*}{ Cohort } & \multirow{2}{*}{$\begin{array}{c}\text { Register } \\
\text { of first } \\
\text { identification }\end{array}$} & \multicolumn{3}{|c|}{ Later identified in school register } \\
\hline & & $\begin{array}{l}\text { Singing } \\
\text { Surf }\end{array}$ & $\begin{array}{l}\text { Local } \\
\text { authority }\end{array}$ & $\begin{array}{c}\text { Calder } \\
\text { Girls }\end{array}$ \\
\hline $\begin{array}{l}\text { Birth cohort } \\
\text { Schools cohort: }\end{array}$ & 1068 & 44 & 565 & 1 \\
\hline $\begin{array}{l}\text { Singing Surf School } \\
\text { Local authority school } \\
\text { Calder Girls School }\end{array}$ & $\begin{array}{r}124 \\
1311 \\
111\end{array}$ & E & $\frac{54}{-}$ & $\begin{array}{r}1 \\
1 \\
-\end{array}$ \\
\hline
\end{tabular}

The birth and schools cohorts do not include all children who were born after 1950 and have lived in Seascale for some period of time. In addition to boys who were pupils only at the excluded preparatory school, any child who, for example, moved to the village after birth but left before school age or went to boarding school elsewhere cannot be identified by the means we have used. The studies, however, will have included most of the Seascale children.

Suitable details of identification for all of these schoolchildren, except those already in the birth cohort, were forwarded to the NHS Central Register, which then provided us with information on deaths, cancer registrations, and emigrations. We were also notified by the Central Register of all family practitioner committee areas, together with dates, in which the children had been recorded as registered with general practitioners. We also obtained dates of starting and leaving school from the registers where available. These details give two indications of dates and duration of residence in or near Seascale. Again, as for births to mothers in Seascale, neither the children nor their parents were approached directly.

In this paper mortality among the children from the time they started school in Seascale until 30 June 1986 is analysed and compared with that expected at national rates. As for the birth cohort, although some of the follow up and deaths in the study are among individuals who have strictly passed childhood, the term children is used throughout the paper to refer to the members of the schools cohort. The person years method of analysis was used, incorporating calendar period, cause, sex, and age specific death rates for England and Wales. Confidence intervals were calculated using standard methods based on the Poisson distribution.

\section{Results}

Table II gives the numbers of children in the schools cohort by school and year of entry to school. An average of under 10 children entered Singing Surf School a year from 1955 to the date of its closure. Entry to the local authority school of children not included in the birth cohort peaked at about 70 children a year during the early 1960 s, with a subsequent fall and secondary peak in the late 1970 s. For Calder Girls School the maximal years of entry were 1960-4, averaging about 15 girls a year.

Table II also shows the numbers of children by age at entry to the three schools, indicating the first age at which they are known to have attended school-and possibly lived-in Seascale. Most children who attended

TABLE II-Numbers of children by year of entry and age at entry to each school

\begin{tabular}{|c|c|c|c|}
\hline & \multicolumn{3}{|c|}{ School } \\
\hline & $\begin{array}{c}\text { Singing Surf } \\
(n=124)\end{array}$ & $\begin{array}{l}\text { Local authority } \\
\quad(n=1311)\end{array}$ & $\begin{array}{c}\text { Calder Girls } \\
(n=111)\end{array}$ \\
\hline \multicolumn{4}{|c|}{ Years of entry to school: } \\
\hline $1950-4$ & 2 & 1 & 0 \\
\hline $1955-9$ & 38 & 202 & 6 \\
\hline $1960-4$ & 42 & 338 & 79 \\
\hline $1965-9$ & 42 & 251 & 25 \\
\hline $1970-4$ & 0 & 187 & 0 \\
\hline $1975-9$ & $\mathbf{0}$ & 204 & 0 \\
\hline $1980-4$ & $\mathbf{0}$ & 128 & 0 \\
\hline Unknown & 0 & 0 & 1 \\
\hline \multicolumn{4}{|c|}{ Age (years) at starting school: } \\
\hline 2 & 6 & 0 & 0 \\
\hline 3 & 44 & 0 & 0 \\
\hline 4 & 58 & 529 & 0 \\
\hline 5 & 10 & 281 & 0 \\
\hline 6 & 3 & 119 & 0 \\
\hline 7 & 1 & 98 & 1 \\
\hline 8 & 2 & 97 & 6 \\
\hline 9 & 0 & 80 & 13 \\
\hline 10 & 0 & 51 & 19 \\
\hline 11 & 0 & 55 & 39 \\
\hline 12 & $\mathbf{0}$ & 1 & 17 \\
\hline 13 & 0 & 0 & 12 \\
\hline 14 & 0 & 0 & 2 \\
\hline 15 & 0 & 0 & 1 \\
\hline Unknown & 0 & 0 & $i$ \\
\hline
\end{tabular}

TABLE III-Vital statistics of children at 30 fune 1986 in each school cohort

\begin{tabular}{lccc}
\hline & \multicolumn{3}{c}{ School } \\
\cline { 2 - 4 } At 30 June 1986 & Singing Surf & Local authority & Calder Girls \\
\hline Alive & 108 & 1177 & 79 \\
Dead & 0 & 10 & 0 \\
Emigrated & 3 & 45 & 17 \\
No trace & 13 & 79 & 15 \\
\hline Total & 124 & 1311 & 111 \\
\hline
\end{tabular}

Singing Surf School entered before 5 years of age. The most frequent ages of entry to the local authority school were 4 and 5 years, even though the 565 children who were born in Seascale and later attended this school are excluded. The numbers who joined the school at older ages indicate the degree of movement of families into the area. An indication of movement out is given by the proportion of children, 545 out of $1173(46 \%)$ with recorded dates of leaving school, who left before the usual age of 11 years. For Calder Girls School starting ages were older and mainly between 9 and 13 years. The median length of time at school in Seascale for all the children was nearly four years, and about $30 \%$ stayed over six years.

Table III summarises the follow up information received from the Central Register for children in the schools cohort by school. Up to 30 June 1986 no deaths were reported among the Singing Surf and Calder Girls schoolchildren 
but there were 10 among the local authority schoolchildren. Overall 65 (4\%) of the children were reported to have left the country. Of 1546 children in the three schools combined, the records of $1439(93 \%)$ were traced in the Central Register. Though this is a high percentage, it compares unfavourably with the $100 \%$ trace rate in the birth cohort where NHS numbers were available.

The deficit is largely among children born before July 1963 for whom the no trace rate was $9 \%$ ( 90 of 1000 births) compared with $3 \%$ (17 of 546) for later births. The reason for this is likely to be related to the fact that between February 1952 and July 1963 the Central Register's alphabetical index was compiled from applications for welfare foods, and about $15 \%$ of parents nationally apparently did not complete the application form issued at birth registration. This limits the searching option to the alternative births index which is more difficult without NHS numbers. In addition, there are inevitably some inaccuracies in the information in the school registers that will have contributed to children not being traced. We know of instances where small errors in, for example, the spelling of the name, have none the less not excluded a successful trace.

Table IV gives mortality figures for the children in the schools cohort compared with national rates. For Singing Surf and Calder Girls Schools, with no deaths reported, the expected numbers from all causes are small at 1.45 and 0.82 respectively. For the children in the local authority school the 10 observed deaths are similar to the 10.42 expected at death rates in England and Wales. For the three schools combined there were 10 observed deaths compared with 12.69 expected-a ratio of 0.79 ( $95 \%$ confidence interval 0.38 to 1.45 ). When examined by cause one of the 10 deaths was certified as due to cancer compared with 2.04 expected-a ratio of $0.49(95 \%$ CI 0.01 to 2.73 ). The particular diagnosis was "malignant melanoma" in a man aged 33 years who had moved away from Seascale. The other nine deaths were all coded under "injury and poisoning" according to the International Classification of Diseases ${ }^{2}$ and consisted of four traffic accidents, three poisonings, one asphyxiation, and one drowning. These nine deaths contrasted with 6.13 expected in this category (observed/ expected $=1 \cdot 47,95 \% \mathrm{CI} 0.67$ to $2 \cdot 79$ ) and included two pairs of siblings. Table $\mathrm{V}$ shows that in no age group were the numbers of observed deaths particularly different from those expected, that mortality was similar to expected for both sexes, and that there was no pattern of deaths by calendar year of follow up.

In addition to the one cancer death, three further cases of cancer were registered between 1971 and 1984 compared with 2.04 non-fatal cases of cancer expected (observed/expected $=1 \cdot 47,95 \%$ CI 0.30 to $4 \cdot 30$ ) using published annual figures for cancer registration by age and sex $^{3}$ and subtracting the number of expected deaths during the same period. All three cases occurred among the local authority schoolchildren. One of these three, a patient with non-Hodgkin's lymphoma diagnosed while living in Seascale,

TABLE IV-Numbers of deaths by cause to 30 fune 1986 among children in each school cohort compared with deaths expected at national rates

\begin{tabular}{|c|c|c|c|c|}
\hline \multirow[b]{2}{*}{ Cause of death ${ }^{\star}$} & \multicolumn{2}{|c|}{ No of deaths } & \multirow[b]{2}{*}{$\mathbf{O} / \mathbf{E}$} & \multirow{2}{*}{$\begin{array}{c}95 \% \\
\text { Confidence } \\
\text { interval } \\
\text { for } \mathrm{O} / \mathrm{E}\end{array}$} \\
\hline & $\begin{array}{l}\text { Observed } \\
\text { (0) }\end{array}$ & $\begin{array}{l}\text { Expected } \\
\text { (E) }\end{array}$ & & \\
\hline \multicolumn{5}{|c|}{ Singing Surf School } \\
\hline $\begin{array}{l}\text { Malignant neoplasms (140-208): } \\
\text { Non-Hodgkin's lymphoma }(200,202) \\
\text { Hodgkin's disease (201) } \\
\text { Leukaemia (204-208) } \\
\text { Other cancers } \\
\text { Other causes } \\
\text { All causes }\end{array}$ & $\begin{array}{l}0 \\
0 \\
0 \\
0 \\
0 \\
0 \\
0\end{array}$ & $\begin{array}{l}0.21 \\
0.02 \\
0.01 \\
0.06 \\
0.12 \\
1 \cdot 24 \\
1 \cdot 45\end{array}$ & $\begin{array}{l}\mathbf{0} \\
\mathbf{0} \\
\mathbf{0} \\
\mathbf{0} \\
\mathbf{0} \\
\mathbf{0} \\
\mathbf{0}\end{array}$ & $\begin{array}{l}0 \text { to } 17 \cdot 23 \\
0 \text { to } 212 \cdot 68 \\
0 \text { to } 272 \cdot 68 \\
0 \text { to } 59 \cdot 89 \\
0 \text { to } 30 \cdot 49 \\
0 \text { to } 2 \cdot 98 \\
0 \text { to } 2 \cdot 54\end{array}$ \\
\hline \multicolumn{5}{|c|}{ Local authority school } \\
\hline $\begin{array}{l}\text { Malignant neoplasms (140-208): } \\
\text { Non-Hodgkin's lymphoma (200, 202) } \\
\text { Hodgkin's disease (201) } \\
\text { Leukaemia (204-208) } \\
\text { Other cancers } \\
\text { Other causes } \\
\text { All causes }\end{array}$ & $\begin{array}{r}1 \\
0 \\
0 \\
0 \\
1 \\
9 \\
10\end{array}$ & $\begin{array}{r}1.63 \\
0.13 \\
0 \cdot 10 \\
0.45 \\
0.94 \\
8 \cdot 79 \\
10 \cdot 42\end{array}$ & $\begin{array}{l}0.61 \\
0 \\
0 \\
0 \\
1 \cdot 06 \\
1 \cdot 02 \\
0.96\end{array}$ & $\begin{array}{l}0.02 \text { to } 3.42 \\
0 \text { to } 29.08 \\
0 \text { to } 35.46 \\
0 \text { to } 8.13 \\
0.03 \text { to } 5.90 \\
0.47 \text { to } 1.94 \\
0.46 \text { to } 1.77\end{array}$ \\
\hline \multicolumn{5}{|c|}{ Calder Girls School } \\
\hline $\begin{array}{l}\text { Malignant neoplasms (140-208): } \\
\text { Non-Hodgkin's lymphoma (200, 202) } \\
\text { Hodgkin's disease (201) } \\
\text { Leukaemia (204-208) } \\
\text { Other cancers } \\
\text { Other causes } \\
\text { All causes }\end{array}$ & $\begin{array}{l}0 \\
0 \\
0 \\
0 \\
0 \\
0 \\
0\end{array}$ & $\begin{array}{l}0.20 \\
0.01 \\
0.01 \\
0.03 \\
0.14 \\
0.62 \\
0.82\end{array}$ & $\begin{array}{l}\mathbf{0} \\
\mathbf{0} \\
\mathbf{0} \\
\mathbf{0} \\
\mathbf{0} \\
\mathbf{0} \\
\mathbf{0}\end{array}$ & $\begin{array}{l}0 \text { to } 18 \cdot 74 \\
0 \text { to } 350 \cdot 94 \\
0 \text { to } 302.65 \\
0 \text { to } 119.05 \\
0 \text { to } 25 \cdot 80 \\
0 \text { to } 5 \cdot 96 \\
0 \text { to } 4.52\end{array}$ \\
\hline
\end{tabular}

^Figures in parentheses are code numbers in the International Classification of Diseases (9th *igures in
revision).
TABLE V-Numbers of deaths by age, sex, and calendar year to 30 fune 1986 among children in local authority school cohort compared with deaths expected at national rates

\begin{tabular}{|c|c|c|c|c|}
\hline \multirow[b]{2}{*}{ Category } & \multicolumn{2}{|c|}{ No of deaths } & \multirow[b]{2}{*}{$\mathrm{O} / \mathbf{E}$} & \multirow{2}{*}{$\begin{array}{l}95 \% \text { Confidence } \\
\text { interval } \\
\text { for } \mathrm{O} / \mathrm{E}\end{array}$} \\
\hline & Observed (O) & Expected (E) & & \\
\hline $\begin{array}{l}\text { Age (years): } \\
\text { Under } 5 \\
5-9 \\
10-14 \\
15-19 \\
20-24 \\
25-29 \\
30 \text { and over }\end{array}$ & $\begin{array}{l}0 \\
0 \\
0 \\
4 \\
2 \\
2 \\
2\end{array}$ & $\begin{array}{l}0.09 \\
1.56 \\
1.51 \\
2.71 \\
2.18 \\
1.46 \\
0.90\end{array}$ & $\begin{array}{l}0 \\
0 \\
0 \\
1 \cdot 47 \\
0.92 \\
1.37 \\
2.23\end{array}$ & $\begin{array}{l}0 \text { to } 41 \cdot 37 \\
0 \text { to } 2 \cdot 37 \\
0 \text { to } 2 \cdot 44 \\
0 \cdot 40 \text { to } 3 \cdot 78 \\
0.11 \text { to } 3 \cdot 31 \\
0.17 \text { to } 4.94 \\
0.27 \text { to } 8 \cdot 06\end{array}$ \\
\hline $\begin{array}{l}\text { Sex: } \\
\text { Male } \\
\text { Female } \\
\text { Calendar year of follow up: }\end{array}$ & $\begin{array}{l}7 \\
3\end{array}$ & $\begin{array}{l}6.85 \\
3.56\end{array}$ & $\begin{array}{l}1.02 \\
0.84\end{array}$ & $\begin{array}{l}0.41 \text { to } 2 \cdot 10 \\
0.17 \text { to } 2 \cdot 46\end{array}$ \\
\hline $\begin{array}{l}1955-9 \\
1960-4 \\
1965-9 \\
1970-4 \\
1975-9 \\
1980-6\end{array}$ & $\begin{array}{l}0 \\
0 \\
2 \\
1 \\
2 \\
5\end{array}$ & $\begin{array}{l}0.20 \\
0.65 \\
1.32 \\
1.95 \\
2.46 \\
3.83\end{array}$ & $\begin{array}{l}0 \\
0 \\
1.51 \\
0.51 \\
0.81 \\
1.30\end{array}$ & $\begin{array}{l}0 \text { to } 18 \cdot 25 \\
0 \text { to } 5 \cdot 65 \\
0 \cdot 18 \text { to } 5 \cdot 46 \\
0.01 \text { to } 2 \cdot 87 \\
0 \cdot 10 \text { to } 2 \cdot 94 \\
0 \cdot 42 \text { to } 3 \cdot 04\end{array}$ \\
\hline Total & 10 & $10 \cdot 42$ & 0.96 & 0.46 to 1.77 \\
\hline
\end{tabular}

was included in the Black report (case 16 of table $2.3^{1}$ ). Of the other two, one is a case of Hodgkin's disease diagnosed in a man aged 26 and the second a carcinoma of the lung diagnosed in a 21 year old woman. These two cases were diagnosed after the patients left Seascale, although one was still resident in Cumbria at the time. In addition, from the Central Register two cases were reported to us of carcinoma in situ of the cervix uteri diagnosed outside Cumbria compared with 1.79 expected between 1971 and 1984 at national rates-a ratio of $1 \cdot 12(95 \% \mathrm{CI} 0 \cdot 14$ to $4 \cdot 04)$. One case was in a 29 year old who had attended Singing Surf School and the other in a 21 year old who had attended the local authority school. Including females in the birth cohort, among whom no cases have been reported, raises the expected number to $2 \cdot 55$-above the two cases observed.

One further case of cancer, diagnosed as "acute lymphocytic leukaemia" while the patient was resident in Seascale, is known to have occurred among these schoolchildren and was included in the Black report (case 2 of table $2.1^{1}$ ). Information from the National Cancer Registration System, however, was not reported to the NHS Central Register before 1971, and hence we were not notified of this case, which was diagnosed in 1968.

\section{Discussion}

This paper reports a follow up study of children who attended one or more of three schools in Seascale but who were not born there. Because they lived for some period of time in Seascale they will have been part of the population at risk of being included as cases in the earlier geographical studies of cancer incidence mortality. Thus it was important to study the records of these children to get as full a picture of Seascale children as possible. Many of the 1546 children moved into Seascale or the nearby area before the usual age of starting school, whereas the remainder came in at later ages. This large degree of movement into the village matched the large movement out that was found in both this study and that of children born to mothers who were resident in Seascale (see accompanying paper).

Given the ages at which the excess of leukaemia mainly occurred in the Seascale birth cohort, most children entered the schools cohort after the maximal age of risk had passed among the births since two of the deaths occurred at age 2 years and a third at age 3 years. These are also the most common ages for the diagnosis of childhood leukaemia in Britain. ${ }^{4}$ Although in the schools cohort overall the expected number of deaths from leukaemia (0.54) was similar to that in the birth cohort $(0.53)$, no deaths from leukaemia were reported compared with five among the birth cohort. The combined figure is five deaths observed compared with 1.07 expected-a ratio of $4.67(95 \%$ CI 1.52 to 10.90$)$. The apparent limitation of the high leukaemia death rate to children born in Seascale is notable, although the lower $95 \%$ confidence limit for the ratio of the rates in the birth cohort to the schools cohort is 0.93 . In terms of cases of cancer one case of leukaemia is known among the 
schoolchildren and diagnosed before 1971 which was the year when the National Cancer Registry first passed on details to the NHS Central Register. Since then three other cases of cancer have been reported in the follow up of these schoolchildren, which is about one more than the expected number (2.04) of non-fatal cases, plus two cases of carcinoma in situ of the cervix uteri compared with 1.79 expected.

Overall 10 deaths were reported among children in the schools cohort compared with 12.69 expected at national rates-a deficit of about $20 \%$. Apart from the one death from cancer the remaining nine deaths were all certified to "injury and poisoning," which is the largest cause of death nationally for the ages that these children have achieved.

Of some concern in this study is the $93 \%$ trace rate of the schoolchildren in the NHS Central Register. The 7\% shortfall may have occurred, for instance, because of inaccuracies in the children's details that were recorded in the three school registers and difficulties in tracing entries in the Central Register from deficiencies in its construction during the early birth years of this study. It is not known whether these deficiencies, which resulted from parents not applying for welfare foods, come from any specific subgroup of families. For this and other reasons we are continuing to investigate ways of successfully identifying the untraced follow up records.
We thank the Registration Division of the Office of Population Censuses and Surveys, the former headmistresses of Singing Surf and Calder Girls Schools, the Cumbrian County Council Education Department, and the headmaster of Seascale School for their cooperation in identifying records on children included in the study. We also thank the National Health Service Central Register for providing follow up details and many staff of the Medical Research Council Environmental Epidemiology Unit who have helped in various ways, particularly $\mathrm{Dr}$ Michael Snee for valuable advice, $\mathrm{Mr}$ Paul Barnard for the computer analyses, and Miss Brigid Grimes for preparing the manuscript. Professor M Bobrow, Dr V Beral, and Dr P G Smith kindly commented on an earlier version of the paper. The study was approved by the British Medical Association Ethical Committee and the West Cumbrian Ethics of Research Committee and was supported partially by a grant from the Department of Health and Social Security.

\section{References}

1 Black D. Investigation of the possible increased incidence of cancer in West Cumbria. London: HMSO, 1984

2 World Health Organisation. Intemational classification of diseases, ninth revision. Geneva: WHO, 1977.

3 Office of Population Censuses and Surveys. Cancer statistics, registrations, 1971-83, England and Wales. London: HMSO, 1979-86. (Series MB1, Nos 1, 2, 4, 5, 7, 8, 10-15.)

4 Draper GJ, Birch JM, Bithell JF, et al. Childhood cancer in Britain: incidence, survival and morality. London: HMSO, 1982. (Office of Population Censuses and Surveys, Studies on Medical and Population Subjects No 37.)

(Accepted 16 fune 1987)

\begin{abstract}
Records on 1068 children who were born to mothers resident in Seascale Civil Parish during 1950-83 were studied. There was a large degree of mobility among the families, and nearly half of the children did not subsequently attend the main local school. Use of the National Health Service Central Register, however, enabled us to follow up the children's records regardless of place of residence. The excess of leukaemia among Seascale children first supported from the analysis of geographical areas is confirmed. There were five deaths from leukaemia identified to 30 June 1986 compared with 0.53 expected at national rates-a ratio of $9.36(95 \%$ confidence interval 3.04 to 21.84$)$. One of these deaths occurred after the child had left Seascale. There were four deaths from other cancers compared with 1.06 expected-a ratio of 3.76 (95\% CI 1.02 to 9.63). In addition, three further cases of cancer, apart from the deaths, were reported compared with 1.19 expected since 1971 - a ratio of $2.53(95 \%$ CI 0.52 to 7.40$)$. For other causes of death, including stillbirths and infant

MRC Environmental Epidemiology Unit (University of Southampton), Southampton General Hospital, Southampton SO9 4XY

$M$ J GARDNER, PHD, professor of medical statistics

A J HALL, MRCP, epidemiologist

$S$ DOWNES, BSC, research assistan

West Cumbria Health Authority, West Cumberland Hospital, Hensingham, Whitehaven, Cumbria CA28 8JG

J D TERRELL, FFCM, district medical officer

Correspondence to: Professor Gardner.
\end{abstract}

mortality, there was a reported deficit compared with national rates, some of which at least was to be expected on the basis of the social class composition of the population of Seascale.

In view of the importance of this cohort of births continued follow up is planned, with the possibility of extending it to include births since 1983, and the methods available for this type of study will be examined further.

\section{Introduction}

In November 1983 a Yorkshire Television programme ("Windscale: the nuclear laundry") suggested that there was an excess incidence of childhood leukaemia in the village of Seascale, which is close to the Sellafield nuclear fuel reprocessing site on the coast of Cumbria. The results of various studies supported this observation and led to the Black inquiry recommending further epidemiological investigations. ${ }^{1}$

Part of the rationale behind the recommendations was that studies of mortality or incidence of disease on a geographical basis suffer from two potential weaknesses. Firstly, they rely on population figures from decennial censuses for the denominators used in the calculation of area rates, whereas the deaths or cases of cancer that form the numerator typically are those that occur in the area over several years before and after a census. Thus no account can be taken of variations in population size from births, deaths, and migrations that will have taken place during these years. Secondly, any deaths or cases of cancer among children who live for some period of time in an area that occur after they have left will not be included in the numerator of the local rate. Such features are of special concern in an area like Seascale where the population, employed largely at Sellafield, is reported to be particularly mobile. ${ }^{1}$ 